\title{
Preliminary Study of the Effects of Vitamin A on Antineoplastic Activities of Chemotherapeutic Agents in Glioma
}

\author{
Eiichi Tani, Tatsuo Morimura, Keizo Kaba \\ and Tetsuya ITAGakI \\ Department of Neurosurgery, \\ Hyogo College of Medicine, \\ Nishinomiva 663
}

\begin{abstract}
Summary
The effects of retinoids on the growth of murine and human gliomas and on the antineoplastic activities of 1-(4-amino-2-methyl-5-pyrimidinyl)methyl-3-(2-chloroethyl)-3-nitrosourea hydrochloride (ACNU) and vincristine were studied. No significant inhibitory effect on proliferation of human glioblastoma (GB) cells in vitro was found 48 hours after administration of $0.003 \mathrm{mg} / \mathrm{ml}$ of retinol acetate. No significant inhibition of murine glioma growth nor significant prolongation of median survival was observed when $70 \mathrm{mg} / \mathrm{kg}$ of retinol palmitate was given every other day 5 times from day 7 after the subcutaneous inoculation of glioma. Significant inhibition of GB cell proliferation by ACNU and vincristine in vitro was dose-dependent. The antitumor effects of ACNU and vincristine in vitro were usually enhanced by $0.003 \mathrm{mg} / \mathrm{ml} \mathrm{of}$ retinol acetate and a statistically significant enhancing effect was found in $10^{-6} \mathrm{~g} / \mathrm{ml}$ of ACNU. The inhibition of tumor growth in vivo induced by ACNU given every other day 5 times was usually enhanced by the addition of $70 \mathrm{mg} / \mathrm{kg}$ of retinol palmitate given 4 hours prior to each $\mathrm{ACNU}$ administration, and its statistical significance was found on day 21 in treatment with $1 \mathrm{mg} / \mathrm{kg}$ of ACNU and on days 21 and 28 in treatment with $10 \mathrm{mg} / \mathrm{kg}$ of $\mathrm{ACNU}$. The increase in median survival induced by ACNU administration was also enhanced by treatment with retinol palmitate, but no statistical significance of enhancement was found. In addition, the percentage cure of subcutaneous glioma was higher in treatment with ACNU plus retinol palmitate than with ACNU alone.
\end{abstract}

Key words: Retinol acetate, retinol palmitate, ACNU, vincristine, glioma

\section{Introduction}

Potentiation of the effects of various chemotherapeutic agents by the membrane-active polyene, amphotericin $\mathrm{B}$, was demonstrated in mouse ependymoblastoma. ${ }^{27,33)}$ Another polyene, vitamin A and some of its naturally occurring and synthetic derivatives (retinoids), exhibit antineoplastic activity. ${ }^{43)}$ Retinoids can prevent the development or cause the regression of hyperplastic lesions in epithelial tumors induced in vivo ${ }^{3,19,37,44)}$ or in vitro ${ }^{7,10,25)}$ by chemical carcinogens. The development of several transplantable tumors in vivo $15,35,46$ ) has also been inhibited by retinoids. In therapy studies it has further been demonstrated that retinoids, applied systematically, increase the cytotoxic action of 1, 3-bis (2-chloroethyl)-1nitrosourea and cyclophosphamide as well as the effect of irradiation on tumor cells. ${ }^{1,5,9)}$ The present preliminary study used murine and human glioma cells in an attempt to examine an antineoplastic activity of retinoids and an enhancement of antitumor effects of chemotherapeutic agents ${ }^{20-22,26,38)}$ by retinoids.

\section{Materials and Methods}

Materials: Glioma induced by methylchol- 
anthrene (MCA) in C57BL/6J mouse was used for in vivo study. When $1 \times 10^{6}$ glioma cells were inoculated subcutaneously in the right flank of C57BL/6J mice, they all took without fail and the animals usually died from tumor growth within 20 to 50 days. Human glioblastoma (GB) cells, which were continuously subcultured in a $10 \mathrm{ml}$ Wheaton culture flask at $37^{\circ} \mathrm{C}$ in a humidified atmosphere of $5 \% \mathrm{CO}_{2}$ and $95 \%$ air in our laboratory, were used for the in vitro study. The culture medium used in the present study was Eagle's minimal essential medium supplemented with $10 \%(\mathrm{v} / \mathrm{v})$ calf serum and $60 \mu \mathrm{g} / \mathrm{ml}$ of kanamycin.

Test compounds: Retinol acetate was purchased from the Sigma Chemical Co., St. Louis, Mo. Vincristine and 1-(4-amino-2methyl-5-pyrimidinyl)methyl-3-(2-chloroethyl)3-nitrosourea hydrochloride (ACNU) were kindly provided by the Shionogi Co., Osaka and Sankyo Co., Osaka, respectively. Retinol palmitate (Eisai Co., Tokyo) used for the in vivo study was a commercial product.

In vitro assay for growth inhibition: Retinol acetate used for the in vitro study was dissolved under $\mathrm{N}_{2}$ in $\mathrm{N}_{2}$-equilibrated dimethyl sulfoxide (DMSO) and sterilized by Millipore filtration (Millipore Corp., Bedford, Mass). The final DMSO concentration in the culture medium was $0.003 \%(\mathrm{v} / \mathrm{v})$, and the final retinol acetate concentrations were $0.003 \mathrm{mg} / \mathrm{ml}$ of culture medium. All procedures with retinol acetate were carried out with interception of light, and the culture plates were completely wrapped by aluminum foil during incubation.

GB cells $\left(1 \times 10^{3} / 200 \mu \mathrm{l}\right.$ of culture medium $)$ were inoculated into Falcon 3040 microtest plate II and incubated for 24 hours at $37^{\circ} \mathrm{C}$ in a humidified atmosphere of $5 \% \mathrm{CO}_{2}$ and $95 \%$ air, and then various concentrations of ACNU and vincristine and/or retinol acetate were added and incubated for 48 hours. Adherent cells were detached with $0.125 \%$ trypsin and $0.01 \%$ EDTA in calcium-free and magnesiumfree phosphate-buffered saline ( $\mathrm{pH} \mathrm{7.4),} \mathrm{and}$ viability was determined with a hemocytometer as the proportion of cells excluding trypan blue. The percent inhibition of proliferation was calculated from the following equation: $100-$ $(\mathrm{R} / \mathrm{C}) \times 100$, where $\mathrm{R}$ is the number of cells in cultures exposed to anticancer drugs and/or retinol acetate and $C$ is the number of cells in control cultures.

In vivo studies of growth inhibition and survival: Mice were inoculated subcutaneously with $1 \times 10^{6}$ MCA-induced glioma cells on day 0 . Treatment with retinol palmitate and/or ACNU was performed intramucularly on days $7,9,11$, 13 , and 15 for 5 times in total. Retinol palmitate was injected in a single dose of $70 \mathrm{mg} / \mathrm{kg}$, and ACNU was injected in a single dose of 1 or $10 \mathrm{mg} / \mathrm{kg}$. When retinol palmitate and ACNU were given, retinol palmitate was injected 4 hours prior to ACNU administration. The tumor size was assessed as the product of the long and short axes of the tumor and percent tumor inhibition was calculated. Statistical differences were assessed by Student's t test. Complete regression was defined as the disappearance of a tumor for at least 1 week. When complete regressions lasted for 2 months or more, they were considered as cures. The life span was expressed as the median day of survival from the time of glioma inoculation, and the percent increase in the median survival [treated/control $(\mathrm{T} / \mathrm{C}) \times 100]$ was estimated. The long-term survivors were defined as animals living for more than 100 days from the time of tumor inoculation. Statistical significance was calculated by the median test.

${ }^{3} H$-vitamin $A$ uptake studies: The kinetics of the uptake of vitamin A was studied by administration of $0.08 \mathrm{mCi}$ of all-trans vitamin $\mathrm{A}_{1}\left[1-{ }^{3} \mathrm{H}(\mathrm{N})\right]$ (New England Nuclear, Boston, Mass) into the peritoneal cavity of C57BL/6J mice. Twelve mice on day 10 after the subcutaneous inoculation of MCA-induced glioma cells were sacrificed $30 \mathrm{~min}, 1,2$, and 4 hours following the administration of ${ }^{3} \mathrm{H}$-vitamin $\mathrm{A}_{1}$. Samples were immediately taken from the glioma, brain and blood, and their wet weights were measured. Then, the samples were treated in a Packard tri-carb sample oxidizer, model 306 , and counted in Parkard liquid scintillation spectrometer 3385 .

Freeze-fracture studies: $\mathrm{GB}$ cells were incubated for 72 hours at $37^{\circ} \mathrm{C}$ in a humidified atmosphere of $5 \% \mathrm{CO}_{2}$ and $95 \%$ air and treated with $10^{-6} \mathrm{~g} / \mathrm{ml}$ of ACNU and/or 
$0.003 \mathrm{mg} / \mathrm{ml}$ of retinol acetate dissolved in $0.003 \%$ DMSO for 20 and 48 hours. The cells were fixed for 20 minutes at $4^{\circ} \mathrm{C}$ in $1 \%$ glutaraldehyde buffered with $0.1 \mathrm{M}$ phosphate (pH 7.4). After gentle harvesting with a rubber spatula, they were centrifuged at $1,000 \mathrm{rpm}$ for 10 minutes. The fixed cell pellets were washed briefly in phosphate buffer and immersed at $4{ }^{\circ} \mathrm{C}$ for 5 hours in a $30 \%$ glycerol solution buffered with the phosphate $(\mathrm{pH}$ 7.4). They were mounted on a copper specimen holder, frozen rapidly in liquid nitrogen, and fractured in vacuo in a HUS-4 freeze-fracture apparatus. The fracture surface was replicated by platinum and carbon. The replica, after digesting the tissue in a commercial bleaching solution, was washed in distilled water, collected on a grid and examined with a HU-12 electron microscope.

\section{Results}

In vitro assay for growth inhibition: The effects of retinol acetate on the proliferation of GB cells and on the antineoplastic activities of ACNU and vincristine are shown in Table 1 .
The proliferation of GB cells was not significantly affected by $0.003 \mathrm{mg} / \mathrm{ml}$ of retinol acetate or $0.003 \%$ DMSO which was used as a solvent for retinol acetate. The inhibitory effects of ACNU and vincristine were dose-dependent as shown in Table 1. The percent inhibition of growth by $0.003 \mathrm{mg} / \mathrm{ml}$ of retinol acetate was $7.3 \%$ in the control group, whereas the percent inhibition increased to $12.9-22.6 \% \quad(p<0.25-$ $\mathrm{p}<0.005$ ) by the addition of $0.003 \mathrm{mg} / \mathrm{ml}$ of retinol acetate to each $\mathrm{ACNU}$ or vincristine administration, except in cases of $10^{-7} \mathrm{~g} / \mathrm{ml}$ of ACNU and $10^{-12} \mathrm{~g} / \mathrm{ml}$ of vincristine.

In vivo studies of growth inhibition and survival: Control and retinol palmitate-treated groups showed a gradual growth of subcutaneous glioma without any regression throughout experiments 1 and 2, and the control tumor growth was greater in experiment 1 than in experiment 2 (Figs. 1 and 2). In retinol palmitate-treated groups, the subcutaneous glioma grew slightly more than the control glioma and no statistical significance was found in tumor sizes of both groups in experiment 1 (Fig. 1 and Table 2). On the other hand, in experiment 2,

Table 1 In vitro effects of vitamin A on antitumor activities of ACNU and vincristine.

\begin{tabular}{|c|c|c|c|c|c|c|}
\hline \multirow[b]{2}{*}{ Drug } & \multirow[b]{2}{*}{ Dose } & \multirow{2}{*}{$\begin{array}{l}\text { Retinol acetate } \\
(0.003 \mathrm{mg} / \mathrm{ml})+ \\
\text { DMSO } 0.003 \%\end{array}$} & \multirow{2}{*}{$\begin{array}{l}\text { No. of viable ceils } \\
\text { (Mean } \pm \text { SD) }\end{array}$} & \multirow[b]{2}{*}{$\%$ Inhibition } & \multicolumn{2}{|c|}{ Significance } \\
\hline & & & & & $p_{1}$ & $\mathrm{p}_{2}$ \\
\hline \multirow[t]{2}{*}{ Control } & & - & $688.9 \pm 226.7(n=10)^{*}$ & & & \\
\hline & & + & $638.9 \pm 175.6(n=8)$ & 7.3 & $>0.5$ & \\
\hline DMSO & $0.003 \%$ & - & $638.9 \pm 227.8(n=8)$ & 7.3 & $>0.5$ & \\
\hline \multirow[t]{6}{*}{ ACNU } & $10^{-6} \mathrm{~g} / \mathrm{ml}$ & - & $370.0 \pm 108.9(n=12)$ & 46.3 & $<0.005$ & \\
\hline & & + & $222.2 \pm 74.4 \quad(\mathrm{n}=10)$ & $67.7(21.4)^{* *}$ & $<0.005$ & $<0.005$ \\
\hline & $10^{-7}$ & - & $500.0 \pm 103.3(n=8)$ & 27.4 & $<0.05$ & \\
\hline & & $\div$ & $388.9 \pm 265.6(n=12)$ & $43.5(16.1)$ & $<0.025$ & $>0.25$ \\
\hline & $10^{-8}$ & - & $555.6 \pm 74.4 \quad(\mathrm{n}=10)$ & 19.3 & $<0.1$ & \\
\hline & & + & $466.7 \pm 172.2(n=10)$ & $32.2(12.9)$ & $<0.025$ & $<0.25$ \\
\hline \multirow[t]{6}{*}{ Vincristine } & $10^{-10}$ & - & $407.8 \pm 173.3(n=12)$ & 40.8 & $<0.005$ & \\
\hline & & + & $277.8 \pm 186.7(n=12)$ & $59.7(18.9)$ & $<0.005$ & $<0.1$ \\
\hline & $10^{-11}$ & - & $488.9 \pm 241.1(n=10)$ & 29.0 & $<0.1$ & \\
\hline & & + & $333.3 \pm 115.6(n=12)$ & $51.6(22.6)$ & $<0.005$ & $<0.1$ \\
\hline & $10^{-12}$ & - & $444.4 \pm 118.9(n=8)$ & 35.5 & $<0.025$ & \\
\hline & & + & $444.4 \pm 145.6(n=8)$ & $35.5(0)$ & $<0.025$ & $>0.5$ \\
\hline
\end{tabular}

* $\mathrm{n}$ indicates the number of wells in Falcon 3040 microtest plate II.

** Number in parentheses shows an increase of percent inhibition by the addition of retinol palmitate administration.

$\mathrm{p}_{1}$ : Significance of treated groups compared to controls.

$\mathbf{p}_{2}$ : Significance of groups treated with vitamin A compared to groups receiving no vitamin A but an identical dose of ACNU or vincristine. 


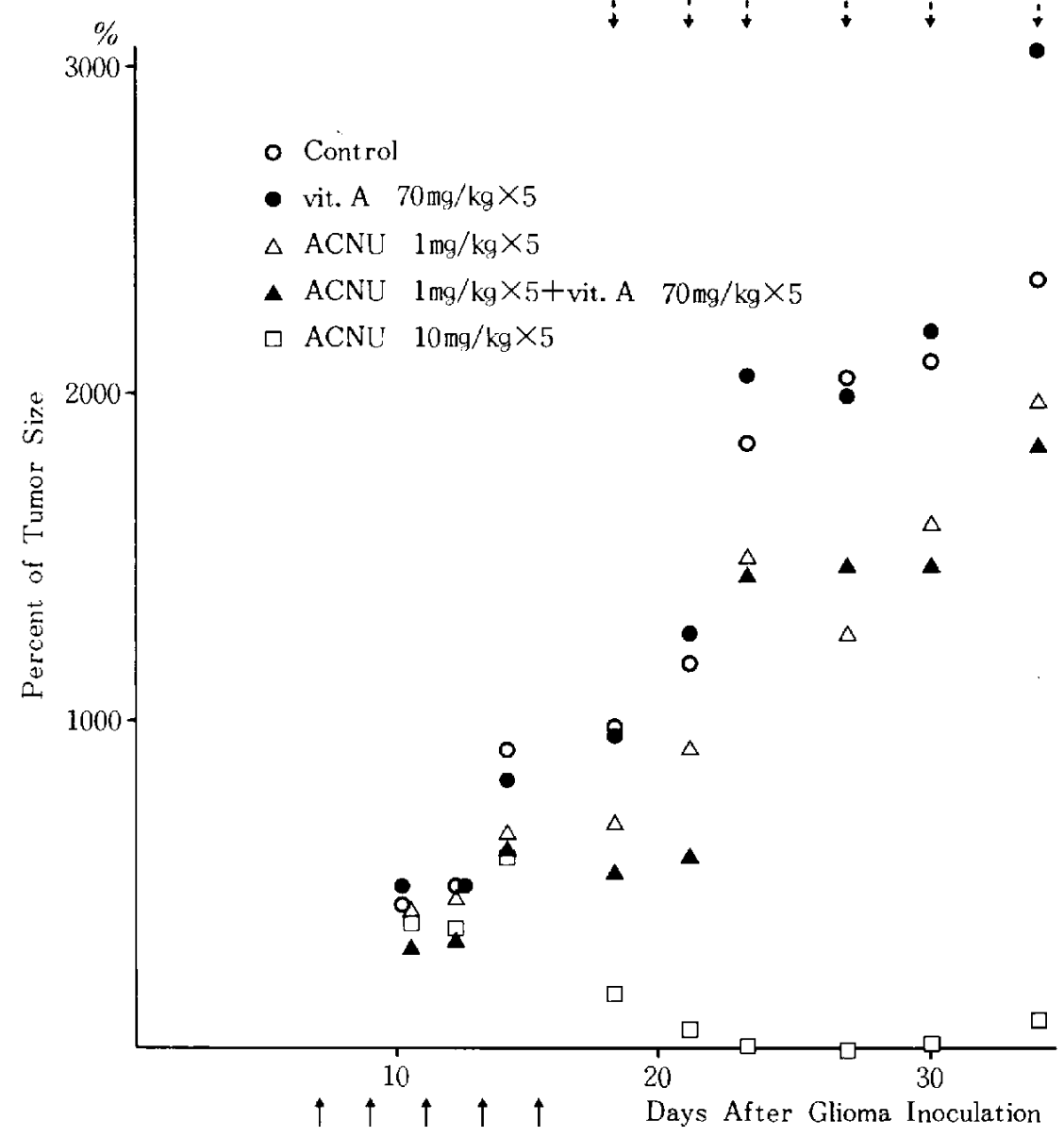

Fig. 1 Changes in tumor size by treatment with ACNU and/or vitamin A in experiment 1 .

Percentage of tumor size on day after glioma inoculation was calculated, taking the tumor size on day 7 as 100 .

1 : indicates day of treatment.

: indicates day of no palpation of tumor. The number above the dotted arrow indicates number of animals without any palpable tumors.

the glioma growth in the retinol palmitatetreated group was slightly inhibited and the statistical differences of tumor size were $p<0.1$ on days 21 and 33 and $\mathrm{p}<0.05$ on day 28 (Fig. 2 and Table 3).

The glioma treated with five serial injections of $1 \mathrm{mg} / \mathrm{kg}$ of ACNU or 5 serial injections of $1 \mathrm{mg} / \mathrm{kg}$ of ACNU plus $70 \mathrm{mg} / \mathrm{kg}$ of retinol palmitate was slightly inhibited, but no statistical significance was evident, except in the group with the latter schedule on day 21 $(\mathrm{p}<0.025)$, when compared with the control
(Fig. 1 and Table 2). The addition of retinol palmitate to ACNU administration in experiment 1 induced a slightly stronger inhibition until day 21 ( $p<0.1$ to $p<0.025$ ), a statistically non-significant enhancement on day 27 and inhibition on and after day 30 (Fig. $I$ and Table 2). When treated with five serial injections of $10 \mathrm{mg} / \mathrm{kg} \mathrm{ACNU}$ or five serial injections of $10 \mathrm{mg} / \mathrm{kg}$ of ACNU plus $70 \mathrm{mg} / \mathrm{kg}$ of retinol palmitate, the glioma growth was significantly inhibited $(\mathrm{p}<0.005)$ after the completion of treatment, and in experiment 1 , non-palpable 
- Control

- vit. A $70 \mathrm{mg} / \mathrm{kg} \times 5$

$\triangle \mathrm{ACNU} 10 \mathrm{mg} / \mathrm{kg} \times 5$

- ACNU $10 \mathrm{mg} / \mathrm{kg} \times 5+$ vit. A $70 \mathrm{mg} / \mathrm{kg} \times 5$

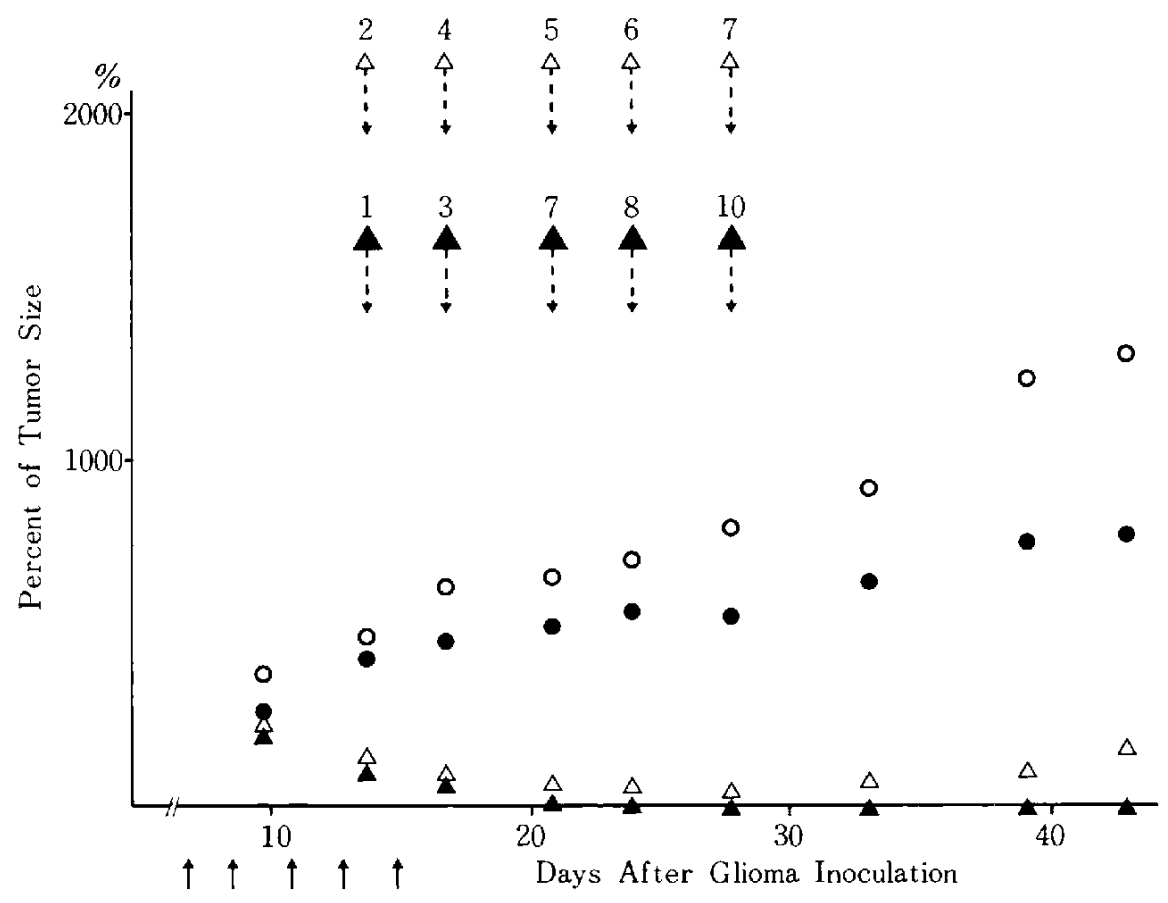

Fig. 2 Changes in tumor size by treatment with $\mathrm{ACNU}$ and/or vitamin $\mathrm{A}$ in experiment 2.

Percentage of tumor size on day after glioma inoculation was calculated, taking the tumor size on day 7 as 100 .

1 : indicates day of treatment.

$1:$ indicates day of a complete regression of tumor in groups treated with ACNU

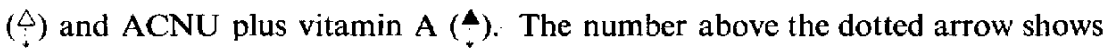
number of animals with complete regression of the tumor.

tumors increased in number in treatment with ACNU until day 27 when all 10 tumors were not palpable and then gliomas increased in size with three complete regressions (Fig. 1 and Table 2). In experiment 2, non-palpable tumors increased in number with time and were found in seven mice treated with ACNU and in all 10 mice treated with ACNU plus retinol palmitate on day 28 (Fig. 2 and Table 3), and finally complete regression was seen in seven out of 10, and all 10 in groups treated with ACNU and ACNU plus retinol palmitate (Table 4). The percent inhibition of tumor growth was usually much greater in the group treated with ACNU plus retinol palmitate than in the group with ACNU alone in experiment 2, and the statistical differences between both groups were $\mathrm{p}<0.5$ on day $10, \mathrm{p}<0.05$ on day $21, \mathrm{p}<0.005$ on day 28 and $\mathrm{p}<0.25$ on day 33 (Table 3). It was also noted that the mean tumor size treated with ACNU again increased from day 33 whereas that treated with ACNU plus retinol palmitate gradually decreased to obtain a complete regression in all the mice in experiment 2 (Figs, 1 and 2).

Detailed effects of ACNU and/or retinol 
Table 2 Effects of ACNU and/or vitamin A on size of subcutaneous mouse glioma.

\begin{tabular}{|c|c|c|c|c|c|c|}
\hline \multirow{2}{*}{$\begin{array}{c}\text { Experiment } \\
1\end{array}$} & \multirow[b]{2}{*}{ Treatment } & \multirow{2}{*}{$\begin{array}{c}\text { Dose } \\
(\mathrm{mg} / \mathrm{kg})\end{array}$} & \multirow{2}{*}{$\begin{array}{c}\text { Tumor size } \\
\text { (Product of long \& } \\
\text { short axes) }\end{array}$} & \multirow{2}{*}{$\begin{array}{l}\% \text { Tumor } \\
\text { inhibition }\end{array}$} & \multicolumn{2}{|c|}{ Significance } \\
\hline & & & & & $\mathrm{p}_{1}$ & $\mathrm{p}_{2}$ \\
\hline \multirow[t]{6}{*}{ Day 14} & 0 & 0 & $407.9 \pm 247.5(\mathrm{n}=20)^{* *}$ & - & - & - \\
\hline & Vitamin A & $70 \times 5$ & $348.0 \pm 111.5(n=9)$ & 15 & $<0.5$ & - \\
\hline & ACNU & $1 \times 5$ & $291.6 \pm 194.5(\mathrm{n}=10)$ & 29 & $<0.25$ & - \\
\hline & ACNU & $1 \times 5$ & $263.7 \pm 128.6(n=10)$ & 35 & $<0.1$ & $>0.5$ \\
\hline & f-Vit. A & $+70 \times 5$ & & & & \\
\hline & ACNU & $10 \times 5$ & $265.2 \pm 120.2(n=10)$ & 35 & $<0.1$ & - \\
\hline \multirow[t]{6}{*}{ Day 21} & 0 & 0 & $532.9 \pm 305.2(n=17)$ & - & - & - \\
\hline & Vitamin A & $70 \times 5$ & $537.9 \pm 89.0 \quad(\mathrm{n}=9)$ & -1 & $>0.5$ & $\cdots$ \\
\hline & $\mathrm{ACNU}$ & $1 \times 5$ & $403.5 \pm 131.1(n=10)$ & 24 & $<0.25$ & - \\
\hline & ACNU & $1 \times 5$ & $253.8 \pm 139.1(\mathrm{n}=10)$ & 52 & $<0.025$ & $<0.025$ \\
\hline & +Vit. A & $+70 \times 5$ & & & & \\
\hline & ACNU & $10 \times 5$ & $33.0 \pm 30.8^{*}(\mathrm{n}=10)$ & 94 & $<0.005$ & - \\
\hline \multirow[t]{6}{*}{ Day 27} & 0 & 0 & $891.4 \pm 462.3(n=13)$ & - & - & - \\
\hline & Vitamin A & $70 \times 5$ & $842.0 \pm 329.9(n=6)$ & 6 & $>0.5$ & - \\
\hline & ACNU & $1 \times 5$ & $570.9 \pm 197.4(n-8)$ & 36 & $<0.1$ & - \\
\hline & ACNU & $1 \times 5$ & $637.7 \pm 294.3(n=9)$ & 28 & $<0.25$ & $>0.5$ \\
\hline & + Vit. A & $+70 \times 5$ & & & & \\
\hline & $\mathrm{ACNU}$ & $10 \times 5$ & $(n=10)$ & 100 & $<0.005$ & \\
\hline \multirow[t]{6}{*}{ Day 34} & 0 & 0 & $1032.9 \pm 405.7(n=10)$ & - & - & - \\
\hline & Vitamin A & $70 \times 5$ & $1287.5 \pm 421.8(n=4)$ & -25 & $>0.5$ & - \\
\hline & $\mathrm{ACNU}$ & $1 \times 5$ & $869.0 \pm 216.1(n=5)$ & 16 & $<0.5$ & - \\
\hline & ACNU & $1 \times 5$ & $785.3 \pm 388.7(n=6)$ & 24 & $<0.25$ & $>0.5$ \\
\hline & Vit. A & $+70 \times 5$ & & & & \\
\hline & ACNU & $10 \times 5$ & $42.0 \pm 102.9^{*}(n=6)$ & 96 & $<0.005$ & \\
\hline
\end{tabular}

* Contains no palpable subcutaneous glioma treated with $10 \times 5 \mathrm{mg} / \mathrm{kg} \mathrm{ACNU}$ in 4 mice on day 21 , in 10 mice on day 27 and in 5 mice on day 34 .

** Number in parentheses shows the number of animals measured for their tumor size.

$\mathrm{p}_{1}$ : Significance of treated groups compared to controls.

$\mathrm{p}_{2}$ : Significance of groups treated with vitamin A compared to group receiving no vitamin A but an identical dose of ACNU.

palmitate on the survival of glioma-bearing mice in experiments 1 and 2 are shown in Figs. 3 and 4. All the control animals were dead due to glioma growth by days 50 and 47 (Figs. 3 and 4) which resulted in median survivals of 35 and 35.5 days in experiments 1 and 2, respectively (Table 4). When treated with five serial administrations of $70 \mathrm{mg} / \mathrm{kg}$ of retinol palmitate, their median days of survival slightly decreased from 35 to $32.5(p>0.5)$ in experiment 1 and slightly increased from 35.5 to 56 $(p<0.25)$ in experiment 2 . There were no long-term survivors in these groups treated with retinol palmitate alone (Table 4). The treatment with five serial injections of $1 \mathrm{mg} / \mathrm{kg}$ of ACNU resulted in a median survival of 37 days $(p>$
0.5 ). If five serial administrations of $70 \mathrm{mg} / \mathrm{kg}$ of retinol palmitate were added to the ACNU injection, the median day of survival slightly increased from 37 to $40(\mathrm{p}<0.5)$ with one long-term survivor out of ten and also slightly increased $(p<0.1)$ when compared with controls (Table 4 ). The treatment with five serial injections of $10 \mathrm{mg} / \mathrm{kg}$ of $\mathrm{ACNU}$ resulted in a median survival of 60.5 days $(\mathrm{p}<0.025)$ with $3 / 10$ long-term survivors in experiment 1 and 250 days $(\mathrm{p}<0.005)$ with $7 / 10 \quad$ long-term survivors in experiment 2. Addition of five serial administrations of $70 \mathrm{mg} / \mathrm{kg}$ of retinol palmitate to the ACNU injection in experiment 2 slightly increased median survival from 250 to $>350$ days $(p<0.5)$ with $10 / 10$ long-term 
Table 3 Effects of ACNU and/or vitamin A on size of subcutaneous mouse glioma.

\begin{tabular}{|c|c|c|c|c|c|c|}
\hline \multirow{2}{*}{$\begin{array}{c}\text { Experiment } \\
2\end{array}$} & \multirow{2}{*}{ Treatment } & \multirow{2}{*}{$\begin{array}{c}\text { Dose } \\
(\mathrm{mg} / \mathrm{kg})\end{array}$} & \multirow{2}{*}{$\begin{array}{c}\text { Tumor size } \\
\text { (Product of long \& } \\
\text { short axes) }\end{array}$} & \multirow{2}{*}{$\begin{array}{l}\% \text { Tumor } \\
\text { inhibition }\end{array}$} & \multicolumn{2}{|c|}{ Significance } \\
\hline & & & & & $\mathrm{p}_{1}$ & $\mathrm{p}_{2}$ \\
\hline \multirow[t]{5}{*}{ Day 10} & 0 & 0 & $213.6 \pm 159.4(\mathrm{n}=10)^{* *}$ & - & - & 一 \\
\hline & Vitamin A & $70 \times 5$ & $152.8 \pm 77.9 \quad(n=10)$ & 28 & $>0.25$ & - \\
\hline & $\mathrm{ACNU}$ & $10 \times 5$ & $118.1 \pm 78.7 \quad(n=10)$ & 45 & $>0.1$ & - \\
\hline & $\mathrm{ACNU}$ & $10 \times 5$ & $100.5 \pm 63.0 \quad(n=10)$ & 53 & $<0.1$ & $>0.5$ \\
\hline & + Vit. A & $+70 \times 5$ & & & & \\
\hline \multirow[t]{5}{*}{ Day 21} & 0 & 0 & $386.9 \pm 81.8 \quad(n=10)$ & - & - & - \\
\hline & Vit. A & $70 \times 5$ & $298.0 \pm 126.0(n=9)$ & 23 & $<0.1$ & - \\
\hline & $\mathrm{ACNU}$ & $10 \times 5$ & $31.5 \pm 41.2 *(\mathrm{n}=10)$ & 92 & $<0.005$ & - \\
\hline & $\mathrm{ACNU}$ & $10 \times 5$ & $11.7 \pm 20.2^{*}(n=10)$ & 97 & $<0.005$ & $<0.05$ \\
\hline & + Vit. A & $+70 \times 5$ & & & & \\
\hline \multirow[t]{5}{*}{ Day 28} & 0 & 0 & $474.8 \pm 157.3(n=9)$ & - & - & - \\
\hline & Vit. A & $70 \times 5$ & $317.3 \pm 104.6(n=7)$ & 33 & $<0.05$ & - \\
\hline & $\mathrm{ACNU}$ & $10 \times 5$ & $19.5 \pm 34.5^{*}(n=10)$ & 96 & $<0.005$ & - \\
\hline & ACNU & $10 \times 5$ & $0^{*} \quad(\mathrm{n}=10)$ & 100 & $<0.005$ & $<0.005$ \\
\hline & + Vit, A & $+70 \times 5$ & & & & \\
\hline \multirow[t]{5}{*}{ Day 33} & 0 & 0 & $530.5 \pm 126.8(n=6)$ & - & - & - \\
\hline & Vit. A & $70 \times 5$ & $386.1 \pm 147.1(n=7)$ & 27 & $<0.1$ & - \\
\hline & $\mathrm{ACNU}$ & $10 \times 5$ & $38.6 \pm 72.6^{*}(n=10)$ & 93 & $<0.005$ & - \\
\hline & ACNU & $10 \times 5$ & $0^{*} \quad(\mathrm{n}=10)$ & 100 & $<0.005$ & $<0.25$ \\
\hline & + Vit. A & $+70 \times 5$ & & & & \\
\hline
\end{tabular}

* Contains complete regression of subcutaneous glioma in 5 mice treated with ACNU and in 7 mice treated with ACNU and vitamin A on day 21, in 7 mice with ACNU and in all mice with ACNU and vitamin A on days 28 and 33.

** Number in parentheses shows the number of animals measured for their tumor size.

$\mathrm{p}_{1}$ : Significance of treated groups compared to controls.

$\mathrm{p}_{2}$ : Significance of groups treated with vitamin A compared to groups receiving no vitamin A but an identical dose of ACNU.

Table 4 Effects of ACNU and/or vitamin A on median day of survival of gliomabearing mice.

\begin{tabular}{|c|c|c|c|c|c|c|c|c|}
\hline \multirow{2}{*}{$\begin{array}{l}\text { Experimen } \\
\text { No. }\end{array}$} & \multirow{2}{*}{ Treatment } & \multirow{2}{*}{$\begin{array}{c}\text { Dose } \\
(\mathrm{mg} / \mathrm{kg})\end{array}$} & \multirow{2}{*}{$\begin{array}{l}\text { No. of } \\
\text { animals }\end{array}$} & \multirow{2}{*}{$\begin{array}{l}\text { Median } \\
\text { day of } \\
\text { survival }\end{array}$} & \multirow{2}{*}{$\begin{array}{l}\% \text { Increase } \\
\text { in MDS }\end{array}$} & \multirow{2}{*}{$\begin{array}{l}\text { No. of long- } \\
\text { term survivors } \\
\text { (>100 days) }\end{array}$} & \multicolumn{2}{|c|}{$\begin{array}{c}\text { Significance } \\
\text { (Median test) }\end{array}$} \\
\hline & & & & & & & $\mathrm{p}_{1}$ & $\mathrm{p}_{2}$ \\
\hline \multirow[t]{6}{*}{1} & 0 & 0 & 20 & 35 & - & 0 & - & - \\
\hline & Vit. A & $70 \times 5$ & 10 & 32.5 & 92.9 & 0 & $>0.5$ & - \\
\hline & $\mathrm{ACNU}$ & $1 \times 5$ & 10 & 37 & 105.7 & 0 & $>0.5$ & - \\
\hline & ACNU & $1 \times 5$ & 10 & 40 & 114.3 & 1 & $<0.1$ & $<0.5$ \\
\hline & + Vit. A & $+70 \times 5$ & & & & & & \\
\hline & $\mathrm{ACNU}$ & $10 \times 5$ & 10 & 60.5 & 172.9 & 3 & $<0.025$ & - \\
\hline \multirow[t]{4}{*}{2} & 0 & 0 & 10 & 35.5 & - & 0 & - & - \\
\hline & Vit. A & $70 \times 5$ & 10 & 56 & 157.7 & 0 & $<0.25$ & - \\
\hline & ACNU & $10 \times 5$ & 10 & 250 & 704.2 & 7 & $<0.005$ & - \\
\hline & $\begin{array}{l}\text { ACNU } \\
+ \text { Vit A }\end{array}$ & $\begin{array}{r}10 \times 5 \\
+70 \times 5\end{array}$ & 10 & $>350$ & $>985.9$ & 10 & $<0.005$ & $<0.5$ \\
\hline
\end{tabular}

MDS: Median Day of Survival.

$p_{1}$ : Significance of treated groups compared to controls.

$\mathrm{p}_{2}$ : Significance of groups treated with vitamin A compared to groups receiving no vitamin A but an identical dose of ACNU. 


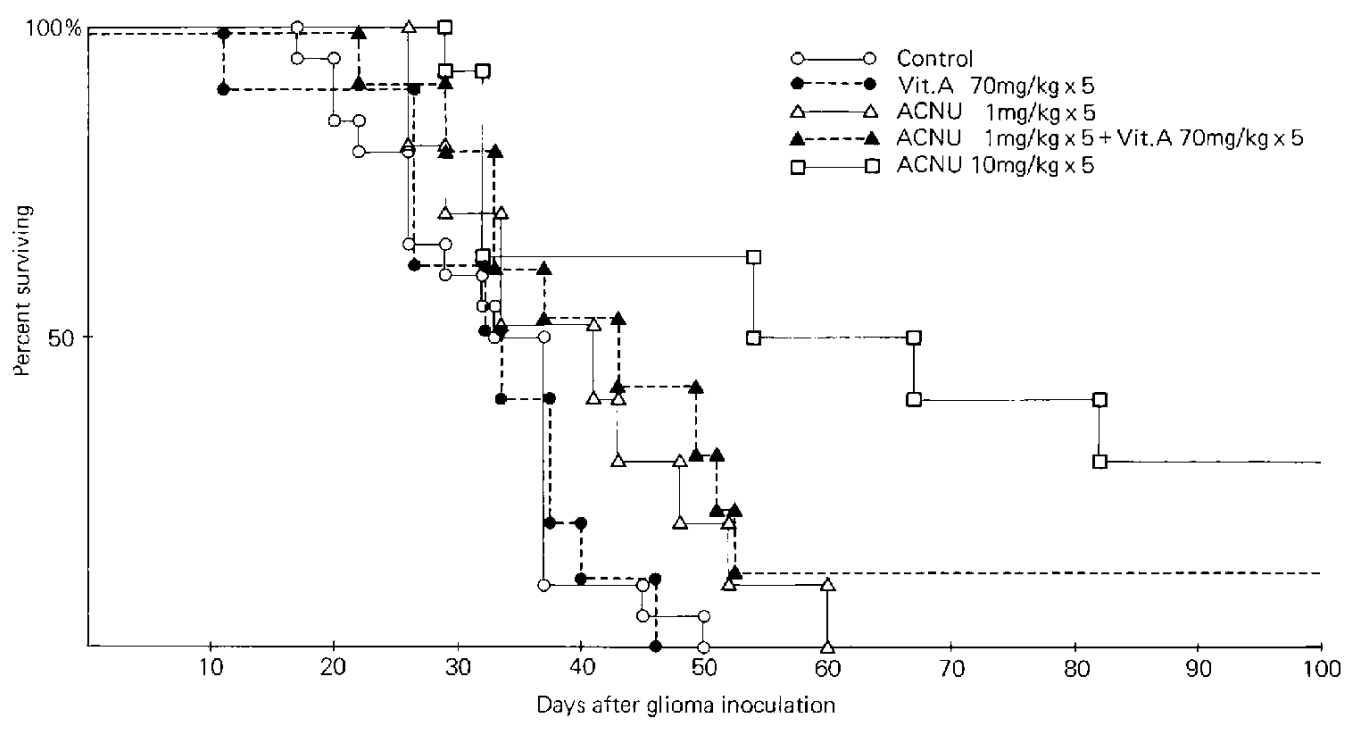

Fig. 3 Effects of ACNU and/or vitamin A on survival time of glioma-bearing mice in experiment 1.

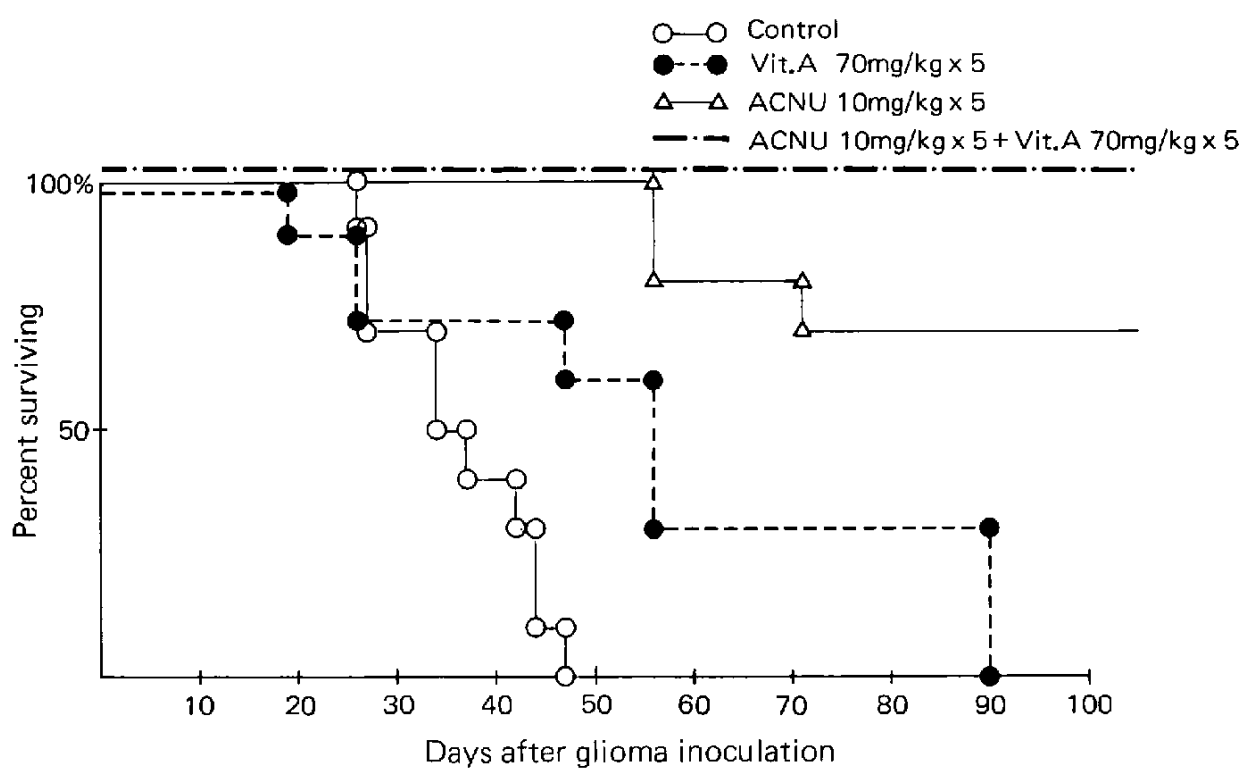

Fig. 4 Effects of ACNU and/or vitamin A on survival time of glioma-bearing mice in experiment 2.

survivors (Table 4).

As side effects, retinol palmitate induced dry skin, particularly in the external ear, alopecia, and seborrhea, and the hair of $\mathrm{C} 57 \mathrm{BL} / 6 \mathrm{~J}$ mice became white with ACNU treatment.

${ }^{3} H$-vitamin $A$ uptake studies (Fig. 5): The blood level of ${ }^{3} \mathrm{H}$-vitamin $\mathrm{A}_{1}$ reached $(5.84 \pm$ $2.57) \times 10^{7}$ and $(5.41 \pm 1.93) \times 10^{7} \mu \mathrm{Ci} / \mathrm{g}$ of wet tissue 1 and 2 hours, and then decreased to $(4.30 \pm 1.19) \times 10^{6} \mu \mathrm{Ci} / \mathrm{g}$ of wet tissue 4 hours after intraperitoneal administration, respectively. On the other hand, the glioma and brain levels of ${ }^{3} \mathrm{H}$-vitamin $\mathrm{A}_{1}$ were $(4.02 \pm$ $3.36) \times 10^{6}$ and $(1.49 \pm 0.15) \times 10^{6} \mu \mathrm{Ci} / \mathrm{g}$ of wet tissue 30 minutes, and $(4.83 \pm 1.96) \times 10^{6}$ and $(2.25 \pm 0.06) \times 10^{6} \mu \mathrm{Ci} / \mathrm{g}$ of wet tissue 1 hour, $(1.45 \pm 0.21) \times 10^{6}$ and $(2.21 \pm 0.29) \times 10^{6} \mu \mathrm{Ci} / \mathrm{g}$ 


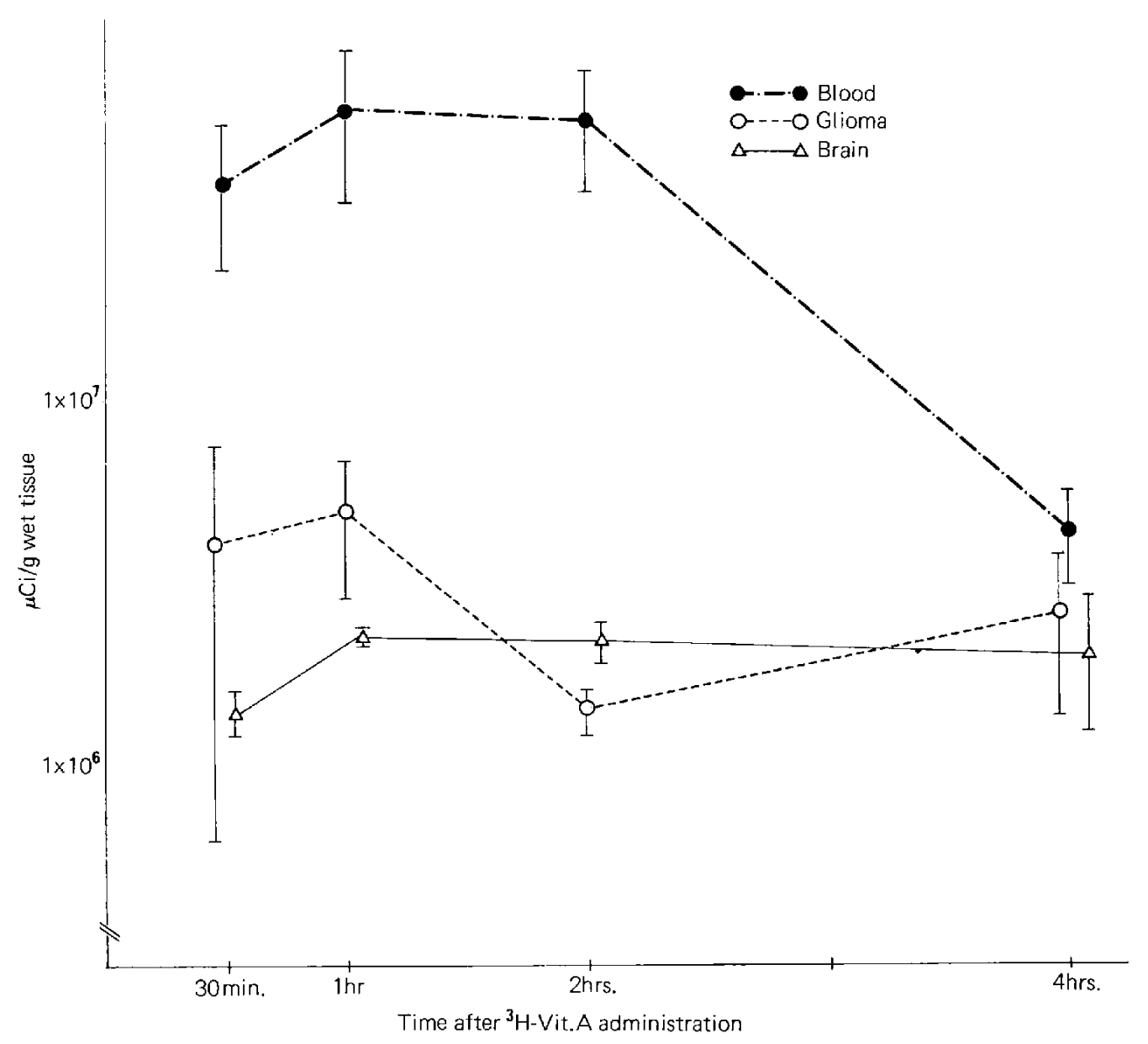

Fig. $5{ }^{3} \mathrm{H}$-vitamin A uptake in glioma, brain and blood.

of wet tissue 2 hours, and $(2.57 \pm 1.19) \times 10^{6}$ and $(2.06 \pm 0.81) \times 10^{6} \mu \mathrm{Ci} / \mathrm{g}$ of wet tissue 4 hours after the intraperitoneal administration, respectively, suggesting a similar uptake in the glioma and brain 4 hours after administration.

Freeze-fracture studies: The cell membrane of $\mathrm{GB}$ cell revealed two fracture faces, $\mathrm{P}$ and $\mathrm{E}$. Many membrane particles were evenly distributed on face $P$, and a small number of membrane particles were seen in a scattered fashion on face E. When treated with $0.003 \mathrm{mg} / \mathrm{ml}$ of retinol acetate in $0.003 \%$ DMSO for 48 hours or with $10^{-6} \mathrm{~g} / \mathrm{ml}$ of ACNU and $0.003 \mathrm{mg} / \mathrm{ml}$ of retinol acetate for 20 hours, many round protrusions and depressions, about $80-360 \mathrm{~m} \mu$ in diameter, were found on faces $P$ and $E$ of some cell membranes (Figs. 6 and 7), indicating a blister protrusion of the cell membrane. The membrane particles in the blistering cell membrane decreased in number.

\section{Discussion}

Retinoids tested in the present preliminary study were $0.003 \mathrm{mg} / \mathrm{ml}$ of retinol acetate in vitro and $70 \mathrm{mg} / \mathrm{kg}$ of retinol palmitate in vivo, and both of these retinoids are the least effective against tumor growth among many retinoids. Retinol acetate and retinol palmitate were not capable of inhibiting significantly the proliferation of glioma cells in vitro and in vivo, except on day 28 in in vivo experiment $2(\mathrm{p}<0.05)$. The median day of survival was not significantly prolonged by treatment with retinol palmitate. Retinol acetate generally enhanced the antitumor effects in vitro of ACNU or vincristine on glioma cells, but a statistically significant effect of enhancement was evident only at a dose of $10^{-6} \mathrm{~g} / \mathrm{ml}$ of ACNU. The inhibition of 

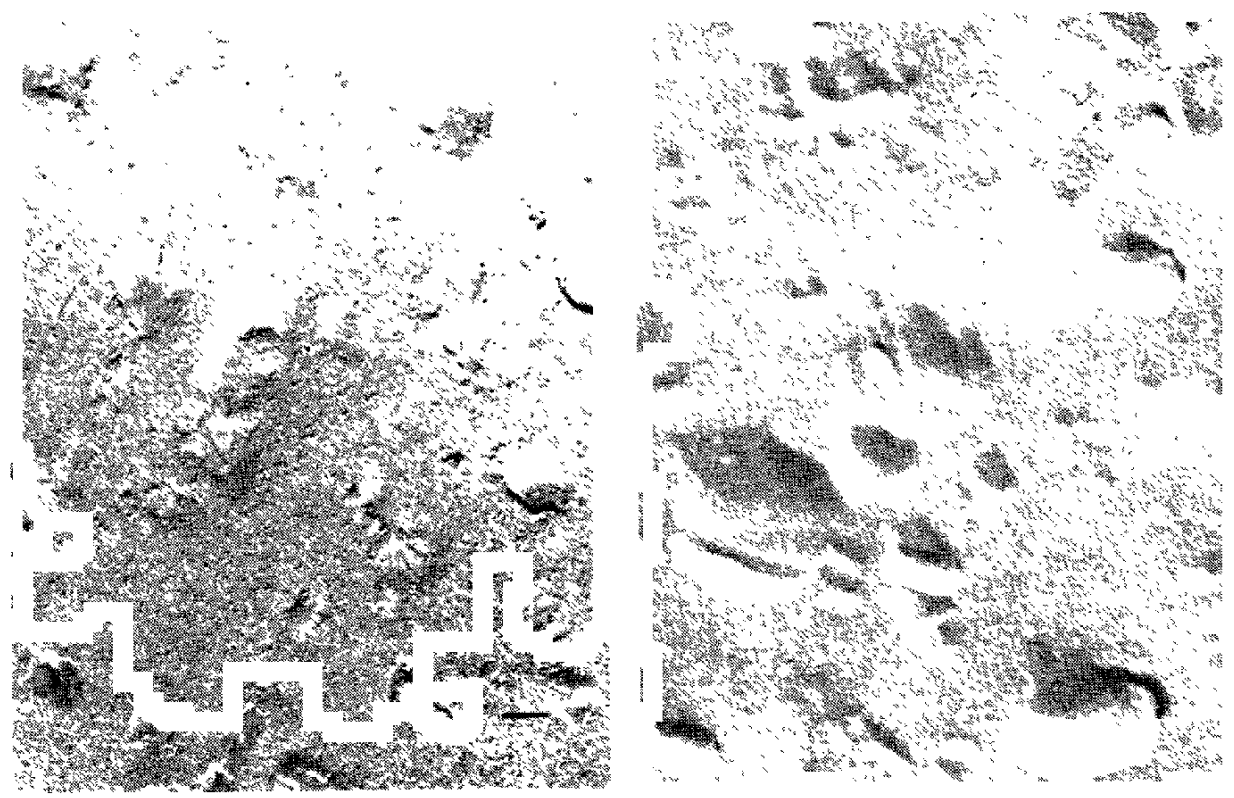

Figs. 6 and 7 Fracture faces of GB cell membranes in vitro. Many blister formations are found on face $E$ treated with $0.003 \mathrm{mg} / \mathrm{ml}$ of retinol acetate for 48 hours and on face $P$ treated with $10^{-6} \mathrm{~g} / \mathrm{ml}$ of ACNU and $0.003 \mathrm{mg} / \mathrm{ml}$ of retinol acetate for 20 hours. The bar in the corner indicates $0.1 \mu$ in length.

tumor growth in vivo induced by $\mathrm{ACNU}$ was also usually enhanced by the addition of retinol palmitate and its statistical significance was found on day 21 in treatment with $1 \mathrm{mg} / \mathrm{kg}$ of ACNU and on days 21 and 28 in treatment with $10 \mathrm{mg} / \mathrm{kg}$ of ACNU. The increase of median survival induced by ACNU administration was also enhanced by treatment with retinol palmitate, but no statistical significance of enhancement was evident. Since the radioactivity of ${ }^{3} \mathrm{H}$-vitamin $\mathrm{A}$ reached a similar level in the glioma to that in the brain 4 hours after the administration, retinol palmitate was given 4 hours prior to the administration of ACNU.

The mechanism of enhancement of the antitumor effect of ACNU by retinoids is unknown. Some studies have suggested that pretreatment with retinoids induces changes in the cell membrane, ${ }^{13,14,18,30,34)}$ which makes the tumor cell more susceptible to the cytolytic action of drugs and immunocytes. ${ }^{6,9,24,45}$ ) Blister formation of the cell membrane was reported in treatment with a high concentration of cryoprotectant such as DMSO and glycerol, ${ }^{31}$ ) but treatment with $0.003 \%$ DMSO in the present study did not result in any blistering of the GB cell membrane. The blister formation of the cell membrane and the cluster formation of the membrane particles occurred during target cell lysis due to lymphotoxin ${ }^{17)}$ and amphotericin B. ${ }^{23)}$ A preliminary study suggests increased penetration of ACNU when GB cells were treated with retinol acetate. Therefore, the enhancement of the antineoplastic activity of ACNU with retinoids may be partly due to cell membrane alterations. Various retinoid-mediated antitumor effects have been attributed to the ability of retinoids to labilize lysosomes. ${ }^{2,5,12,16,36,40.48)}$ On the other hand, direct determinations of free lysosomal enzymes in the cytoplasm of murine melanoma cell lines $\mathrm{S} 91$ and $\mathrm{B} 16$, which are sensitive to inhibition of growth by retinoic acid, did not show any increased release of lysosomal acid phosphatase. ${ }^{29)}$

Some investigations suggest an indirect and nonspecific mechanism by which retinoids, acting as adjuvants, enhance host immune response against the tumor cells. ${ }^{2,11,15,32,35,39 \text {, }}$ The lack of an antitumor effect with five serial injections of $70 \mathrm{mg} / \mathrm{kg}$ of retinol palmitate in the present in vivo study cannot always corroborate or contradict the above suggestions 
because retinoids have been reported to increase the host survival in nitrosoureainduced rat spongioblastoma, ${ }^{1}$ and detailed immunological studies are necessary to confirm the immune response of retinoids in glioma. The present in vitro studies obviously pointed out the possible importance of direct inhibition of glioma cell proliferation by retinoids.

There are some conflicting statements concerning the effect of retinoids on carcinogenesis and tumor growth. Whereas some studies found promotion of tumor growth, ${ }^{18,28,41,42,47)}$ many authors have reported the antitumor activity of retinoids and the enhancement of the cytotoxic action of chemotherapeutic agents and irradiation by retinoids. However, the systemic application of retinoids induced a series of side effects ${ }^{4)}$ and its utility in the therapy of glioma is limited because of the toxic side effects. Currently, attempts are being made to synthesize new analogs of retinoids which may be more effective against tumors and less toxic than retinol acetate or retinol palmitate. ${ }^{8}$ ) Since retinol acetate or retinol palmitate, both of which are the least effective against tumor growth among retinoids, suggested the enhancement of antineoplastic activity of $A C N U$ in glioma, retinoid therapy seems to be promising. In addition, it is necessary for satisfactory therapy to determine the optimal doses of retinoids and chemotherapeutic agents and to make a reasonable treatment schedule against glioma.

\section{Acknowledgment}

The authors thank Miss Yuhko Itoh, Miss Miyuki Ikemoto, and Mr. Nobue Furukawa for their technical assistance and Miss Atsuko Manabe for her typing of the munuscript.

\section{References}

1) Allen, N., Clendenon, N. R., Denlinger, R. and Kartha, M. K.: Effect of vitamin A on radiation enhancement and survival in experimental rat gliomas. Trans Am Neurol Assoc 102: 160-163, 1977.

2) Bollag, W.: Effects of vitamin A acid on transplantable and chemically induced tumors. Cancer Chemother Rep 55: 53-55, 1971.

3) Bollag, W.: Prophylaxis of chemically induced benign and malignant epithelial tumors by vitamin $\mathrm{A}$ acid (retinoic acid). Eur $J$ Cancer 8: 689-693, 1972.

4) Bollag, W.: Therapy of epithelial tumors with an aromatic retinoic acid analog. Chemotherapy 21 : 236-247, 1975.

5) Brandes, D., Rundell, J. O. and Ueda, H.: Radiation response of $\mathbf{L} 1210$ leukemia cells pretreated with vitamin A alcohol. $J$ Natl Cancer Inst 52: 945-949, 1974.

6) Brandes, D., Sato, T., Ueda, H. and Rundell, J. O.: Effect of vitamin A alcohol on the surface coat and charges of L1210 leukemic cells. Cancer Res 34: 2151-2158, 1974.

7) Chopra, D. P. and Wilkoff, L. J. : Inhibition and reversal by $\beta$-retinoic acid of hyperplasia induced in cultured mouse prostate tissue by 3-methylcholanthrene or $\mathrm{N}$-methyl-N'-nitronitrosoguanidine. J Natl Cancer Inst 56: 583589, 1976.

8) Chopra, D. P. and Wilkoff, L. J.: Reversal by vitamine A analogues (retinoids) of hyperplasia induced by N-methyl-N'-nitro-N- nitrosoguanidine in mouse prostate organ cultures. $J$ Natl Cancer Inst 58: 923-930, 1977.

9) Cohen, M. H. and Carbone, P. P.: Enhancement of the antitumor effects of 1, 3-bis (2chloroethyl)-1-nitrosourea and cyclophosphamide by vitamine A. $J$ Natl Cancer Inst 48: 921-926, 1972.

10) Crocker, T. T. and Sanders, L. L.: Influence of vitamin $A$ and 3, 7-dimethyl-2, 6-octadienal (citral) on the effect of benzo(a) pyrene on hamster trachea in organ culture. Cancer Res 30: 1312-1318, 1970.

11) Dennert, G., Crowley, C., Kouba, J. and Lotan, R.: Retinoic acid stimulation of the induction of mouse killer T-cells in allogeneic and syngeneic systems. $J$ Natl Cancer Inst 62 : 89 94, 1979.

12) Dingle, J. T.: Studies on the mode of action of excess vitamin A. III. Release of a bound protease by the action of vitamin A. Biochem J 79: 509-512, 1961.

13) Dingle, J. T. and Lucy, J. A.: Studies on the mode of action of excess of vitamin A. 5. The effect of vitamin A on the stability of the erythrocyte membrane. Biochem $J$ 84: 611621, 1962.

14) Dingle, J. T. and Lucy, J. A.: Vitamin A, carotinoids and cell function. Biol Rev 40: 422-461, 1965.

15) Felix, E. L., Loyd, B. and Cohen, M. H.: Inhibition of the growth and development of a transplantable murine melanoma by vitamin A. Science 189: 886-888, 1975.

16) Fell, H. B., Dingle, J. T. and Webb, M.: 
Studies on the mode of action of vitamin A. The specificity of the effect on embryonic chick-limb cartilage in culture and on isolated rat-liver lysosomes. Biochem $J$ 83: 63-69, 1962.

17) Friend, D. S. and Rosenau, W.: Target-cell membrane alterations induced by lymphotoxin. Ultrastructural observations. $A m J$ Pathol 86: 149-162, 1977.

18) Glauert, A. M., Daniel, M. R., Lucy, J. A. and Dingle, J. T.: Studies on the mode of action of excess of vitamin A. VII. Changes in the fine structure of erythrocytes during haemolysis by vitamin A. J Cell Biol 17: 111-121, 1963.

19) Grubbs, C. J., Moon, R. C., Sporn, M. B. and Newton, D. L.: Inhibition of mammary cancer by retinyl methyl ether. Cancer Res 37: 599602, 1977.

20) Gutin, P. H., Wilson, C. B., Kumar, A. R. V., Boldrey, E. B., Levin, V., Powell, M. and Enot, K. J.: Phase II study of procarbazine, $\mathrm{CCNU}$, and vincristine combination chemotherapy in the treatment of malignant brain tumors. Cancer 35: 1398-1404, 1975.

21) Hasegawa, H., Hayakawa, T., Hori, M., Nakagawa, H., Mogami, H. and Nakata, Y.: Chemotherapy of experimental glioma with nitrosoureas-comparison of water soluble ACNU and lipid soluble Me-CCNU. Brain and Nerve 29: 891-898, 1977.

22) Hori, M., Nakagawa, H., Hasegawa, H., Mogami, H., Hayakawa, T. and Nakata, Y.: Chemotherapy of malignant glioma with the new nitrosourea derivative (ACNU). Cancer Chemother 5: 773-778, 1978.

23) Kitajima, Y., Sekiya, T. and Nozawa, Y.: Freeze-fracture ultrastructural alterations induced by filipin, pimaricin, nystatin and amphotericin B in the plasma membranes of Epidermophyton, Saccharomyces and red blood cells. A proposal of models for polyneergosterol complex-induced membrane lesions. Biochim Biophys Acta 445: 452-465, 1976.

24) Komiyama, S., Hiroto, I., Kuwano, M., Endo, H. and Koga, K.: Enhancement of radiation effect on transformed fibroblastic cells by a synergistic combination of 5fluorouracil and polyenes in vitro. Gann 65: 85-87, 1974.

25) Lasnitzki, I. : Reversal of methylcholanthreneinduced changes in mouse prostates in vitro by retinoic acid and its analogs. $B r J$ Cancer 34: 239-248, 1976.

26) Lassman, L. P., Pearce, G. W. and Gang, J.: Sensitivity of intracranial gliomas to vincristine sulphate. Lancet 1:296-298, 1965.
27) Laurent, G., Atassi, G. and Hildebrand, J.: Potentiation of 1-(2-choroethyl)-3-cyclohexyl1-nitrosourea by amphotericin $B$ in murine ependymoblastoma. Cancer Res 36: 40694073, 1976.

28) Levij, I. S. and Polliack, A.: Potentiating effect of vitamin A on 9-10-dimethyl-1-2benzanthracene. Carcinogenesis in the hamster cheek pouch. Cancer 22: 300-306, 1969.

29) Lotan, R., Giotta, G., Nork, E. and Nicolson, G.: Characterization of the inhibitory effects of retinoids on the in vivo growth of two malignant murine melanomas. $J$ Natl Cancer Inst 60: 1035-1041, 1978.

30) Matter, A. and Bollag, W.: A fine structural study on the therapeutic effect on an aromatic retinoid on chemically-induced skin papillomas of the mouse. Eur J Cancer 13: 831-838, 1977.

31) McIntyre, J. A., Gilula, N. B. and Karnovsky, M. J.: Cryoprotectant-induced redistribution of intramembranous particles in mouse lymphocytes. J Cell Biol 60: 192-203, 1974.

32) Meltzer, M. S. and Cohen, B. E.: Tumor suppression by Mycobacterium bovis (strain BCG) enhanced by vitamin A. J Natl Cancer Inst 53: 585-587, 1974.

33) Muller, P. J. and Tator, C. H.: The effect of amphotericin $\mathrm{B}$ on the survival of braintumor-bearing mice treated with CCNU. $J$ Neurosurg 49: 579-588, 1978.

34) Murphy, M. J.: Effects of vitamin A on the erythrocyte membrane surface. Blood 41: 893-899, 1973.

35) Rettura, G., Schittek, A., Hardy, M., Levenson, S. M., Demetriou, A. and Seifter, E.: Antitumor action of vitamin $\mathrm{A}$ in mice inoculated with adenocarcinoma cells. $J$ Natl Cancer Inst 54: 1489-1491, 1975.

36) Rundell, J. O., Sato, T., Wetzelberger, E., Ueda, $\mathrm{H}$ and Brandes, D.: Lysosomal enzyme release by vitamin A in L1210 leukemia cells. $J$ Natl Cancer Inst 52: 1237-1244, 1974.

37) Saffiotti, U., Montesano, R., Sellakumar, A. R. and Borg, S. A.: Experimental cancer of the lung. Inhibition by vitamin $A$ of the induction of tracheobronchial squamous metaplasia and squamous cell tumors. Cancer 20: 857-864, 1967.

38) Saito, Y., Nakaya, Y., Muraoka, K. and Fujiwara, T.: Chemotherapy of brain tumors with nitrosourea derivative (ACNU). Cancer Chemother 5: 779-794, 1978.

39) Seifter, E., Zisblatt, M., Levine, N. and Rettura, G.: Inhibitory action of vitamin A on a murine sarcoma. Life Sci 13: 945-952, 
1973.

40) Shamberger, P. J.: Inhibitory effect of vitamin A on carcinogenesis. $J$ Natl Cancer Inst 47: 667-673, 1971.

41) Smith, D. M., Rogers, A. E., Herndon, B. J. and Newberne, P.: Vitamin A (retinyl acetate) and benzo(a) pyrene-induced respiratory tract carcinogenesis in hamsters fed a commercial diet. Cancer Res 35: 11-16, 1975.

42) Smith, W. E., Yazdi, E. and Miller, L.: Carcinogenesis in pulmonary epithelia in mice on different levels of vitamin A. Environ Res 5: 152-163, 1972.

43) Sporn, M. B., Dunlop, N. M., Newton, D. L. and Smith, J. M.: Prevention of chemical carcinogenesis by vitamin $\mathrm{A}$ and its synthetic analog (retinoids). Fed Proc 35: 1332-1338, 1976.

44) Sporn, M. B., Squire, R. A., Brown, C. C. and Smith, J. M.: 13-Cis-retinoic acid: Inhibition of bladder carcinogenesis in the rat. Science 195: 487-489, 1977.

45) Tripoldi, D., Parks, L. and Brugmans, J.: Drug induced restoration of cutaneous delayed hypersensitivity reactions in cancer patients. $N$ Engl J Med 289: 354-357, 1973.

46) Trown, P. W., Buck, M. J. and Hansen, R.: Inhibition of growth and regression of a transplantable rat chondrosarcoma by three retinoids. Cancer Treat Rep 60: 1647-1653, 1976.

47) Weiss, L. and Holyoke, E. D.: Some effects of hypervitaminosis $A$ on metastasis of spontaneous breast cancer in mice. $J$ Natl Cancer Inst 43: 1045-1054, 1966.

48) Weissman, G.: Labilization and stabilization of lysosomes. Fed Proc 23: 1038-1044, 1964. 